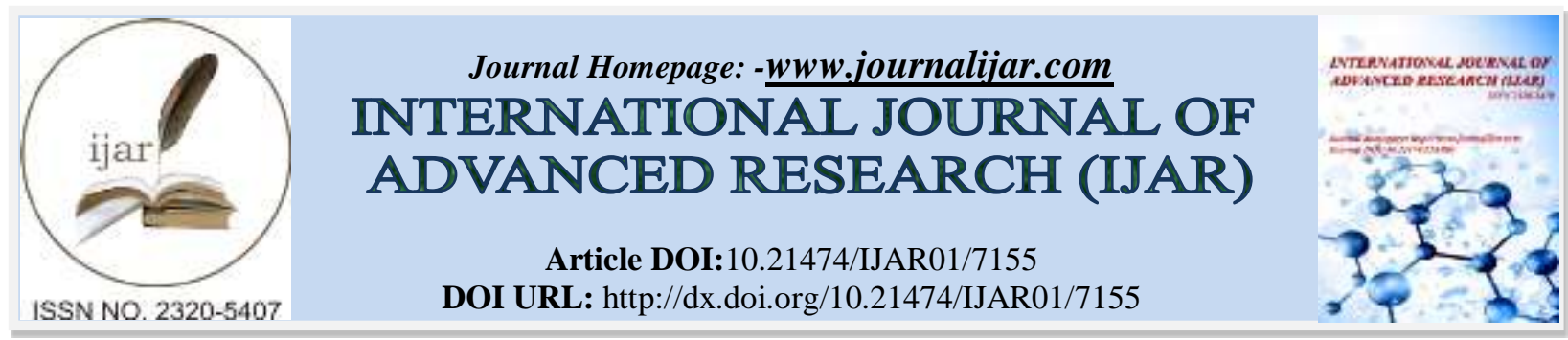

RESEARCH ARTICLE

\title{
EVALUATION OF THE PHYSICO-CHEMICAL QUALITY OF WATERS USED IN IRRIGATION IN THE PERIMETER OF THE WASTEWATER TREATMENT PLANT OF DAR EL GUEDDARI.
}

\author{
S. Njimat*, H. Griou, M. Aboulouafa and S. Ibn Ahmed. \\ Laboratory of Materials, Electrochemistry and Environment. Department of Chemistry - Faculty of Science - Ibn \\ Tofail University - Kenitra - Morocco.
}

\section{Manuscript Info}

Manuscript History

Received: 20 March 2018

Final Accepted: 22 April 2018

Published: May 2018

Keywords:-

wastewater treatment, Dar El Gueddari, physico-chemical quality of the water.

\begin{abstract}
The present study concerns the evaluation of the quality of the water used in irrigation in the perimeter of the DAR EL GUEDDARI wastewater treatment plant, these waters are often purified water coming from the WWTP and sometimes water pumped into the canal. rejection from the Sebou wadi. For this, we realized a set of measures such as: the temperature, the $\mathrm{pH}$, the electrical conductivity, the biochemical demand in oxygen BOD5, the chemical demand in oxygen COD, the suspended matter MES, the total nitrogen ( $\mathrm{N}$ ( tot), ammonium NH4 +, nitrates NO3-, total phosphorus P (tot), orthophosphate PO43-, sulphates $\mathrm{SO} 42-$, sodium $\mathrm{Na}+$, chlorides $\mathrm{Cl}-$, potassium $\mathrm{K}+$, metals such as: $\mathrm{Cr}, \mathrm{Cd}, \mathrm{Pb}, \mathrm{Hg}, \mathrm{Cu}, \mathrm{Mn}, \mathrm{Fe}$ and $\mathrm{Zn}$ The results obtained during this study indicate that the physicochemical quality of the WWTP water used for crop irrigation does not always meet the irrigation water criteria in agriculture (Moroccan standard for irrigation water). They are characterized by low levels of dissolved oxygen, high levels of TSS, BOD5, COD and sodium and low levels of heavy metals such as $\mathrm{Cd}, \mathrm{Pb}, \mathrm{Hg}, \mathrm{Cu}, \mathrm{Mn}$. The combination of the electrical conductivity $\mathrm{CE}$ and the SAR sodium absorption coefficient according to the irrigation water classification diagram of RISVERD allows to classify these waters in the box of poor quality water. However, the water pumped into the sewage disposal canal from Oued Sebou is likely to meet the criteria set by the Moroccan standard for irrigation. On average, they are less rich in nutrients (NPK) with moderately lower values than wastewater from the WWTP and they are characterized by low levels of sodium, conductivity, SAR and pose no risk of salinization or alkalization; with the exception of nitrates, which have an average value of $4.2 \mathrm{mg} / \mathrm{l}$.
\end{abstract}

Copy Right, IJAR, 2018,. All rights reserved.

\section{Introduction:-}

The reuse of wastewater in agriculture is a very old practice in several countries of the world, it has been developed around large cities where volumes are very important [1]. In this sense, particular interest has been given to this reuse, particularly in arid and semi-arid countries, because of the scarcity of renewable water resources on the one hand and agricultural intensification via demographic growth on the other. part [2]. In Morocco, depletion and overexploitation of water resources and the repetitiveness of years of drought have negatively influenced the 
availability of water resources [3], this water stress has led the Moroccan state through several stakeholders in the water and agriculture sector to realize several experimental projects in the field of wastewater reuse in agriculture, such as watering green areas [4]. In DAR EL GUEDDARI, agriculture is one of the main axes of development of the region. In fact, the growing need and demand for water in the face of the cost of collecting irrigation water pushed residents of DAR EL GUEDDARI's WWTP to the agricultural use of wastewater with intensive unregulated reuse accompanied by lack of knowledge of the risks of this practice on the physico-chemical quality of the soil (salinisation, alcalinisation). This reuse is mainly for fodder crops such as alfalfa, forage maize and sorghum on about twenty hectares. The objective of this work is to evaluate the physicochemical quality of the wastewater at the exit of the Dar El Gueddari wastewater treatment plant and the water pumped into the discharge channel from the Wadi Sbou for their use for purposes farm.

\section{Materials and methods:-}

\section{Study area:-}

The present study took place in DAR EL GUEDDARI, located in the region of Rabat-Salé-Kenitra at a distance of $92 \mathrm{~km}$ from the capital of Morocco, on the regional road ${ }^{\circ} 411$ leading to the city of Bel ksiri (Fig.1), it had about 6873 inhabitants in 2014 [5]. the climate of the study area is humid to semi-arid influenced by the Atlantic Ocean with a temperate winter; annual rainfall reaches $500 \mathrm{~mm} /$. Summer temperatures are high with a maximum of $45^{\circ} \mathrm{C}$ [6]. Domestic wastewater is collected and transferred through a pumping station at the WWTP which is of the natural lagoon type with secondary treatment (two anaerobic basins + two optional basins) with a daily flow around $500 \mathrm{~m} 3 /$ day. The treated wastewater is discharged into the R'DOM canal and reused in agriculture. 


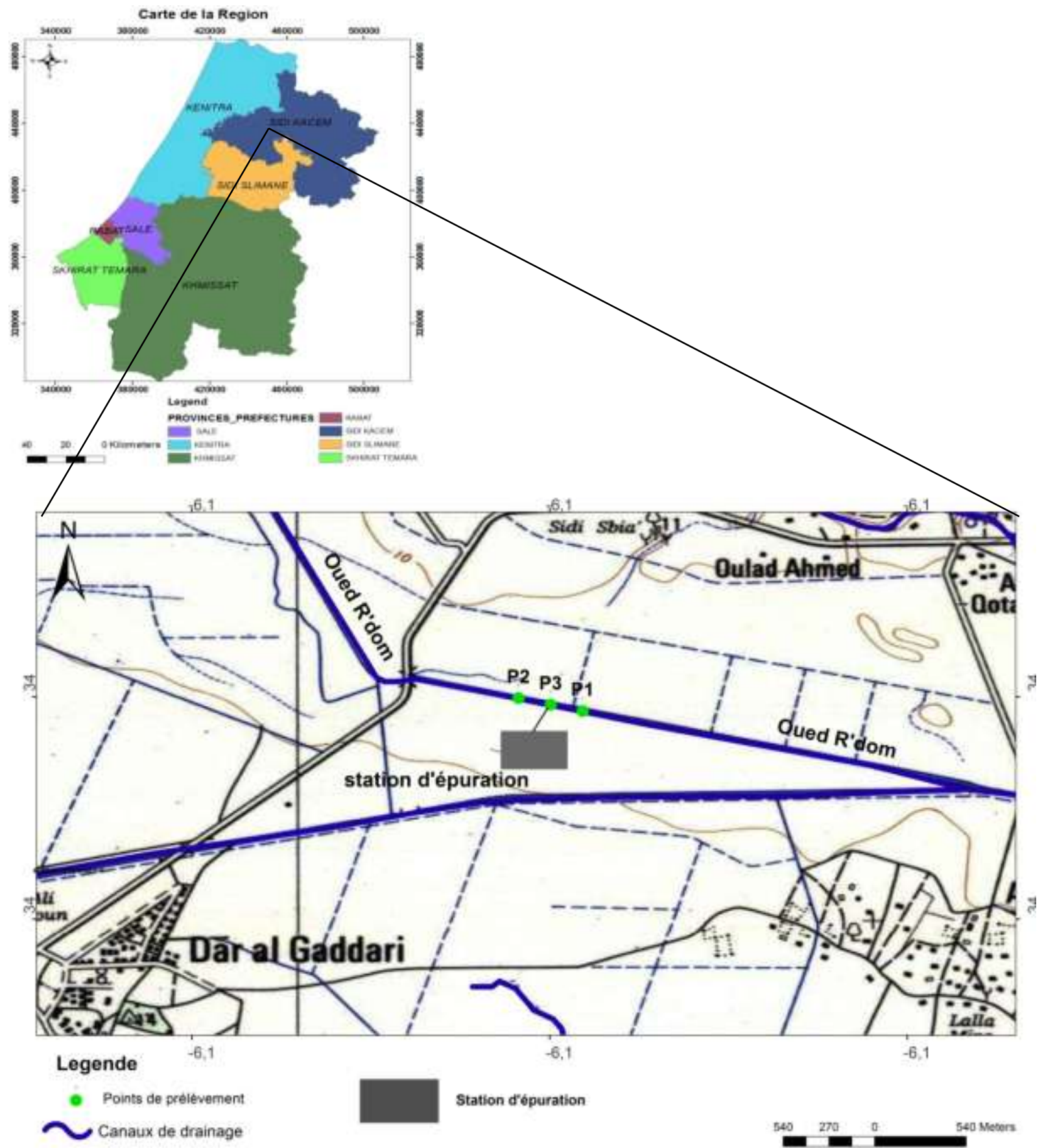

Fig.1:-Situation map of the Dar El Gueddari WWTP

\section{Choice of sampling points:-}

To realize this study, three sampling sites were chosen and designated by:

P1:- upstream of the discharge of the WWTP: this point includes the water pumped into the R'DOM canal from the Oued SEBOU to satisfy the water requirement of the rice crop, this type of pumping remains periodic,

P2:-downstream of the WWTP discharge: this includes the treated wastewater from the WWTP and the upstream water when it occurs.

Samples from these two points are taken from the middle of the channel.

P3:-at the exit of the station: it includes only the purified water of the WWTP. 
Frequency and sampling method:-

A sampling frequency, twice per season, was conducted during the summers of 2016 and 2017. All samples are 24hour composite types by an auto-sampler.

\section{Parameters and methods of wastewater analysis:-}

All samples are taken in polyethylene polyethylene bottles. The sampling, fixation and conservation conditions according to the CEAEQ standard DR-09-04 and ONEP's rules of good practice [7-8] are well respected, temperature, $\mathrm{pH}$, dissolved oxygen and the electrical conductivity are measured in situ. Other parameters such as chemical oxygen demand (COD), biochemical oxygen demand for 5 days (BOD5), suspended matter (MSS), total nitrogen (Ntot), ammonium NH4 +, nitrates $\mathrm{NO}_{3} \mathrm{SO}_{4}{ }^{2-}$ sulphates, $\mathrm{Na}^{+}$sodium, ortho-phosphate $\mathrm{PO}_{4}{ }^{3-}, \mathrm{Cl}^{-}$chlorides. Potassium $\mathrm{K}^{+}$, total phosphorus (Ptot), $\mathrm{Cr}, \mathrm{Cd}, \mathrm{Pb}, \mathrm{Hg}, \mathrm{Cu}, \mathrm{Mn}, \mathrm{Fe}$ and $\mathrm{Zn}$ are determined in the laboratory. The $\mathrm{pH}$ and temperature were determined by a $\mathrm{pH}$-meter type CONSORT C831 equipped with a temperature sensor [9]. Biochemical oxygen demand for 5 days (BOD5) was determined by the OxiTop method [10]. Total nitrogen (Ntot), ammonium NH4 +, nitrates NO3-, sulphates SO42-, sodium Na +, ortho-phosphate PO43-, chloride Cl-. Potassium $\mathrm{K}+$ and total phosphorus (Ptot) are determined by the continuous flow method [11-14]. For measurements of COD and MES, they are carried out respectively by the colorimetric method [12] and the gravimetric method [13] with a 5 $\mu \mathrm{g}$ precision BAXTRANE balance. For $\mathrm{Cr}, \mathrm{Cd}, \mathrm{Pb}, \mathrm{Hg}, \mathrm{Cu}, \mathrm{Mn}, \mathrm{Fe}$ and $\mathrm{Zn}$, they are determined by ICP-MS [14].

\section{Results and discussions:-}

Variation in temperature, electrical conductivity, $\mathrm{pH}$ and dissolved oxygen
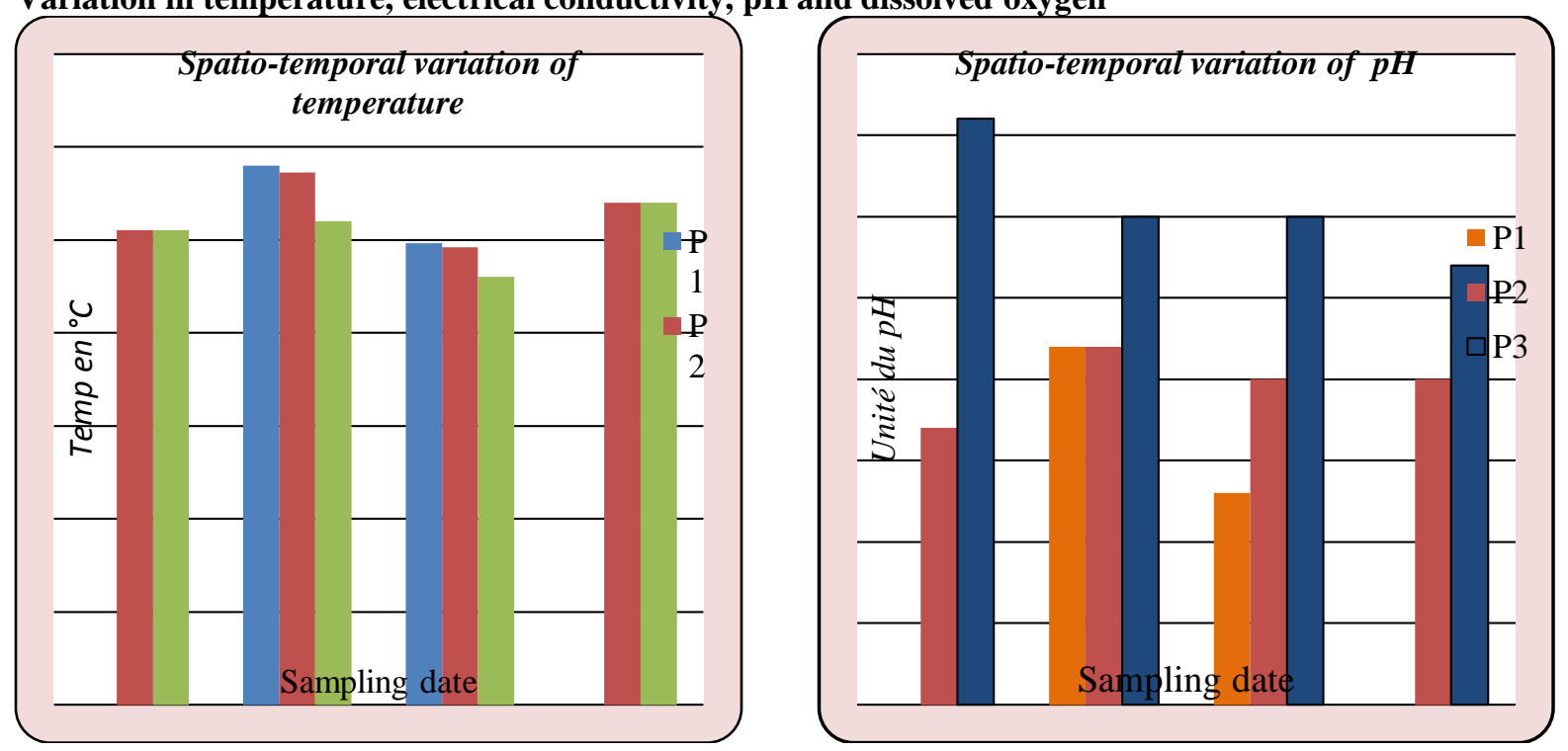

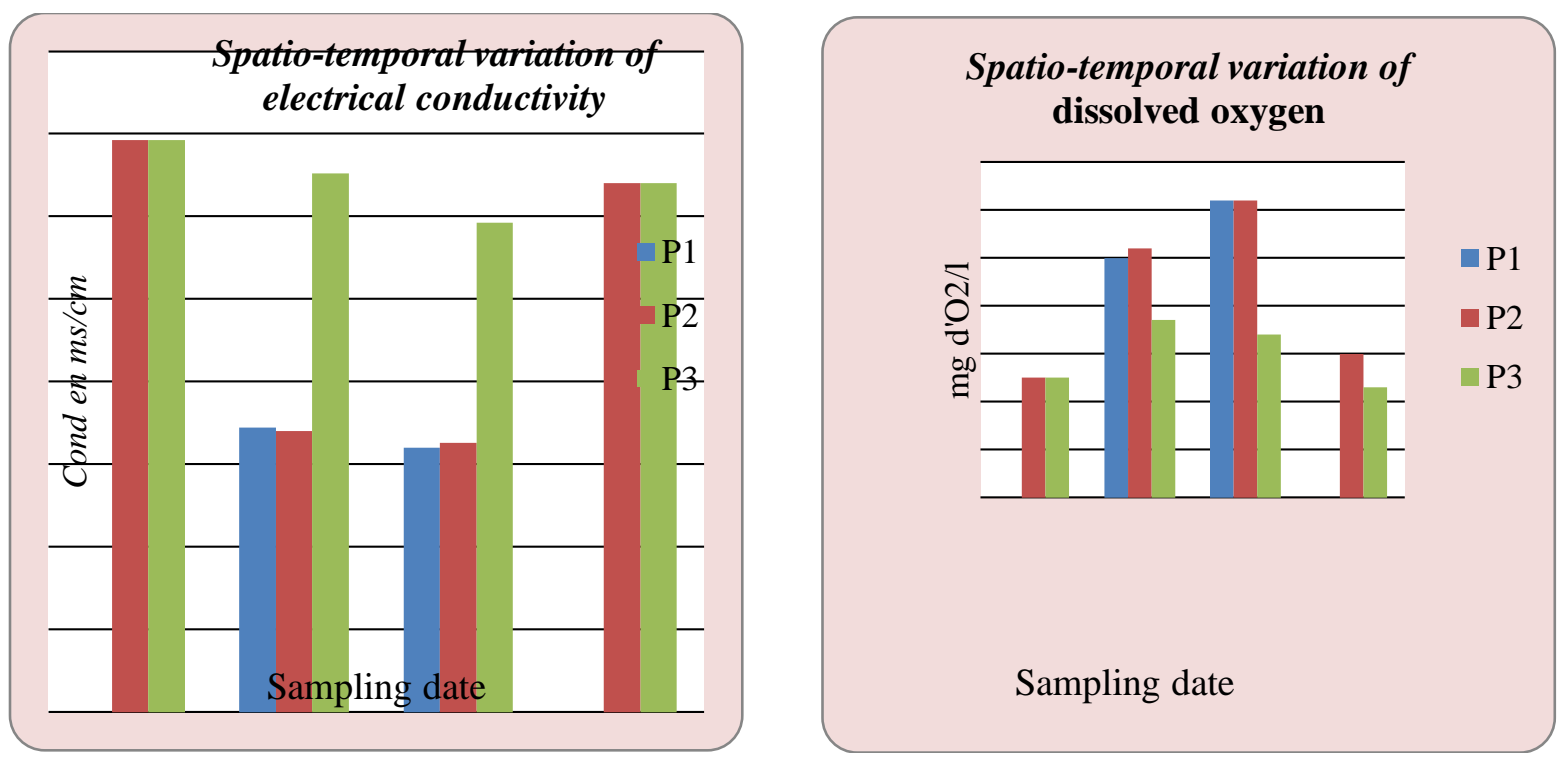

Fig.2:-Spatio-temporal variation of temperature, electrical conductivity, $\mathrm{pH}$ and dissolved oxygen.

pH:-

The $\mathrm{pH}$ does not differ significantly from one sampling point to another, it oscillates around 8.00. These values are within the range of the direct discharge limits and the Moroccan standard for water destined for irrigation which is between 6.5 and 8.5 [15-16].

\section{Temperature:-}

Temperature is an ecological factor that affects the density, viscosity, solubility of gases and even chemical and biochemical reactions, the development and growth of microorganisms living in water. In the study area, the water temperature at the exit of the WWTP of the Dar El Gueddari city is between $25^{\circ} \mathrm{C}$ and $27^{\circ} \mathrm{C}$ with an average of 26.22. That of the upstream and downstream channel is between 22.8 and $29^{\circ} \mathrm{C}$ with an average of $26.53^{\circ} \mathrm{C}$. These recorded temperatures are linked to climatic variations and remain within the range of the direct discharge limit values in the receiving environment of the Moroccan standard for water quality intended for irrigation.

\section{Conductivity:-}

The electrical conductivity is the expression of the load of the dissolved salts, it allows to evaluate the global mineralization by the quantity of ions in solution. For surface irrigation, the maximum value of the electrical conductivity for irrigation is fixed at $3 \mathrm{~ms} / \mathrm{cm}$ [16]. The results of the measurements of all the samples at the exit of the station are all higher than $2.96 \mathrm{~ms} / \mathrm{cm}$. This value is far from the value found in the drinking water of the city of Dar El GUEDDARI and is $0.75 \mathrm{~ms} / \mathrm{cm}$. This variation is generally related to users' activities. The values upstream and downstream of the point of discharge of the WWTP remain acceptable, they vary between 1.6 and $1.72 \mathrm{~ms} / \mathrm{cm}$.

\section{Dissolveed oxygen:-}

In our study area, dissolved oxygen levels vary depending on the type of effluent. In general, water from Wadi Sbou is a little rich in oxygen with values between 5.2 and $6.2 \mathrm{mg} / \mathrm{L}$. This concentration can be explained by the warming of the water during the summer months. the slow flow rate, which gives a great opportunity to the microorganisms consuming oxygen. For the output of the station, the values found during the two study series are low, with an average of $2.97 \mathrm{mg} / \mathrm{l}$. This decrease can be explained by the strong demand for dissolved oxygen of microorganisms for the biodegradation of the material (high COD and BOD5 at the exit of the station). 
Variation of COD, BOD5 and MES:-
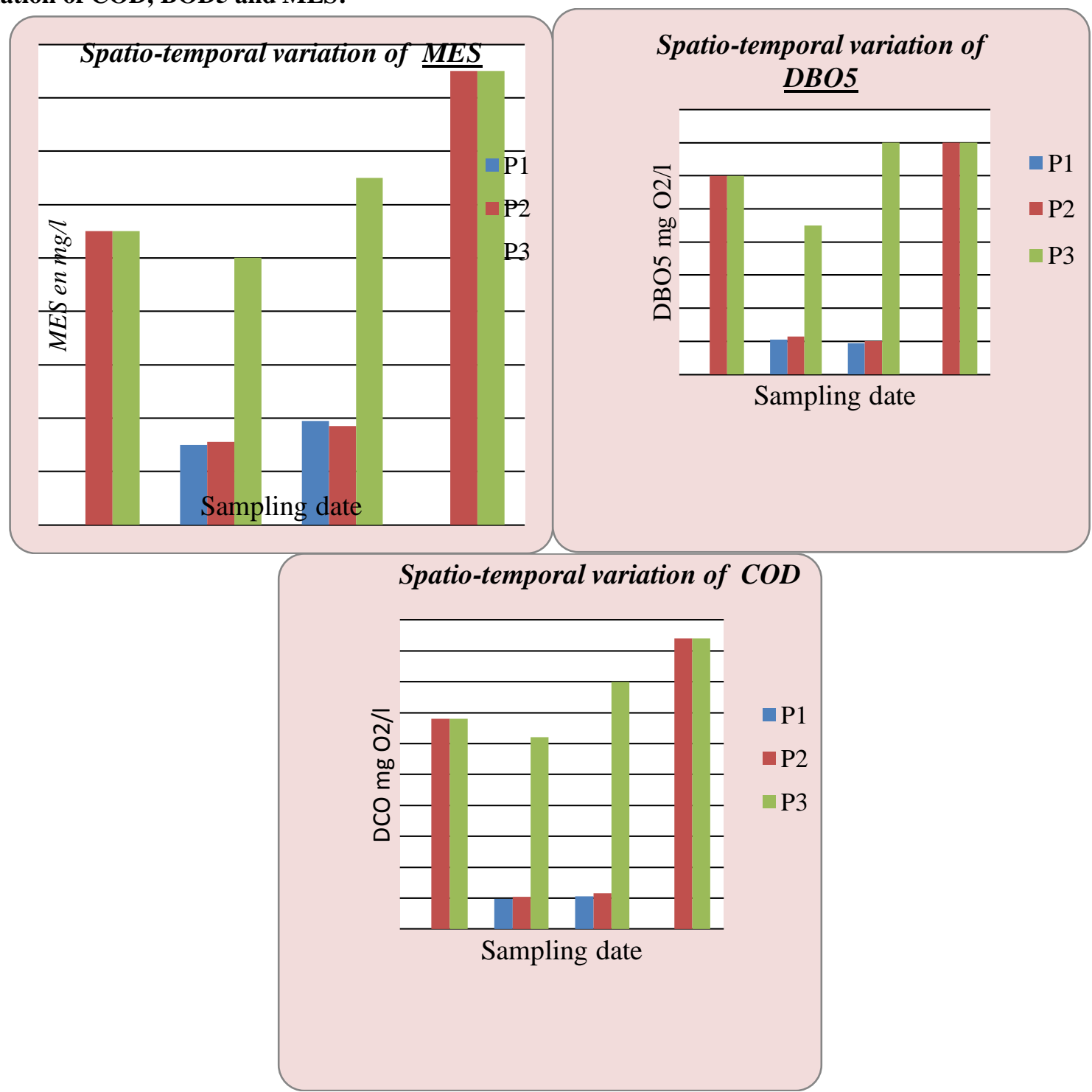

Fig.3:-Variation of COD, BOD5 and MES

The presence of large amounts of suspended solids (SS) in irrigation water causes sedimentation on the boards, which clogs the soil and can reduce percolation [17]. The results for suspended solids (SS), the biochemical oxygen demand BOD5 and the COD oxygen demand (Fig.3) for wastewater from the WWTP are relatively high compared to the discharge values set by the Moroccan standard for liquid discharges. [15] with mean values of $128 \mathrm{mg} / \mathrm{l}$, $117 \mathrm{mg} / \mathrm{l}$ and $380 \mathrm{mg} / \mathrm{l}$, respectively. These results are similar to those found in a further study [18] in the study of monitoring performance of the station. The values recorded during the study period for the pumped water do not exceed $20 \mathrm{mg} \mathrm{O} / \mathrm{l}$ for BOD5 and $58 \mathrm{mgO} / / \mathrm{l}$ for COD. The average value of $34 \mathrm{mg} / \mathrm{l}$ in MES results from debris of vegetation and erosion of the edges of the canal. 
Variation in the content of major nutrients:-

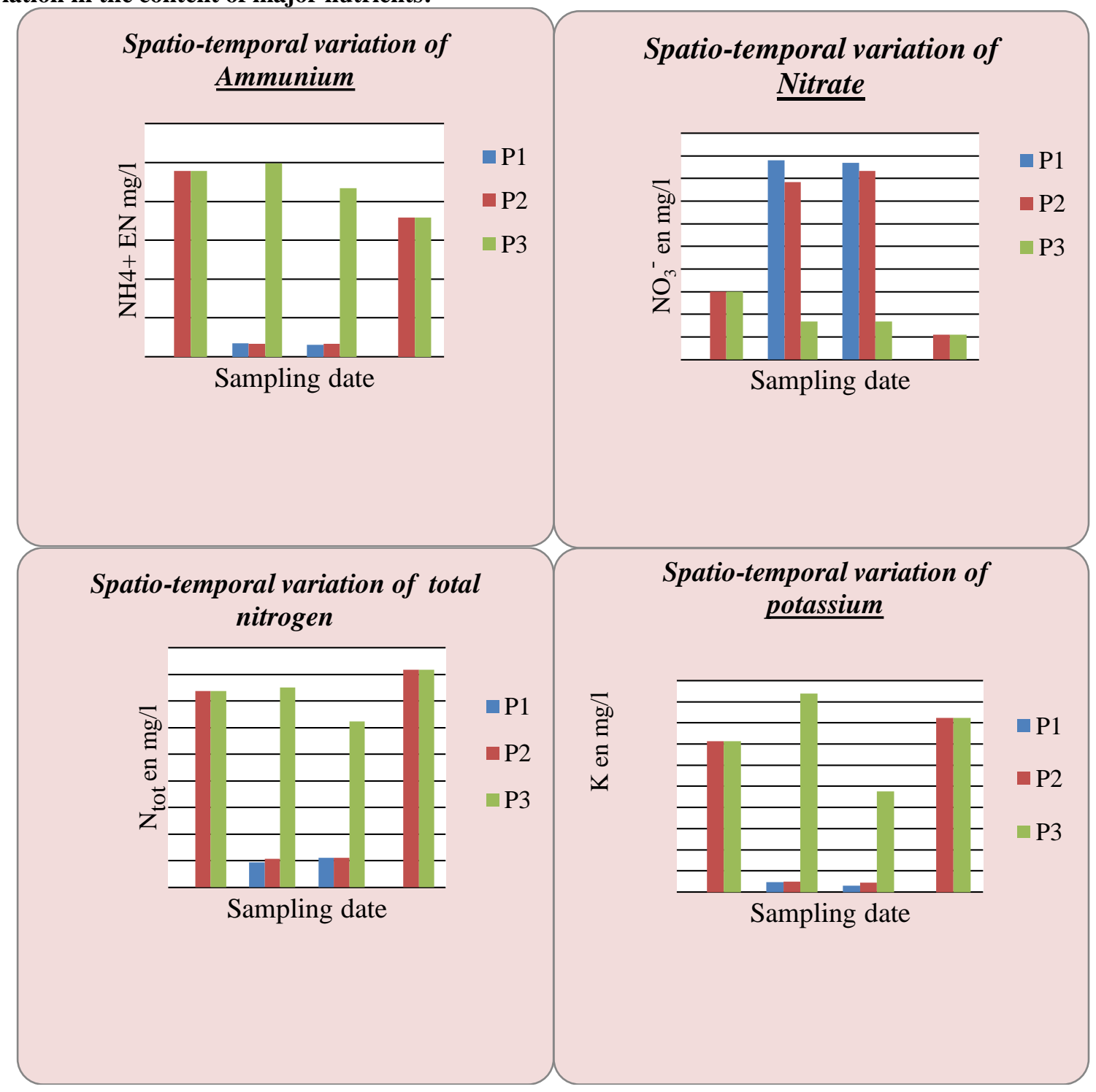




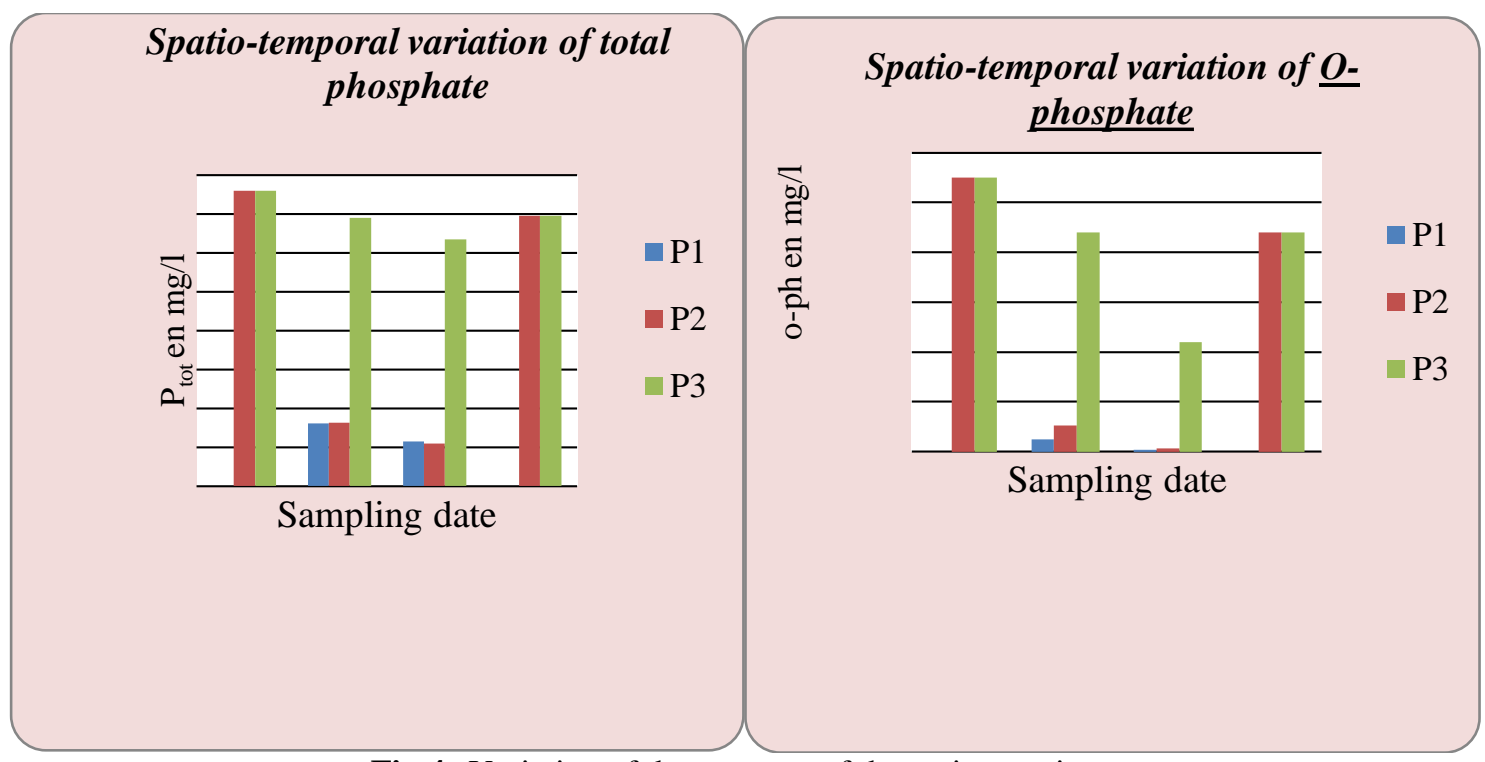

Fig.4:-Variation of the contents of the major nutrients

Variation in the content of minor nutrients:-

Wastewater can provide the major nutrients that have a positive impact on soil fertility and plant productivity [17]. Knowledge of the content of these elements in the used wastewater is important because it allows a reasoned use of water resources. In this study, we determined the contents of Ntot, $\mathrm{N}-\mathrm{NH}_{4}, \mathrm{~N}_{-} \mathrm{NO}_{3}, \mathrm{Ptot}, \mathrm{PO}_{4}{ }^{3-}$ and $\mathrm{K}^{+}$. The results obtained are illustrated in Figure 4. The analysis of these results shows that the EUT of the WWTP of DAR EL GUEDARI are rich in nitrogen with average values of $78 \mathrm{mg} / \mathrm{l}$. In comparison with data provided in the literature, the nitrogen content after secondary treatment is generally between 20 and $60 \mathrm{mg} / \mathrm{l}$ [19]. The average value of the total phosphate is $11 \mathrm{mg} / \mathrm{l}$ whereas the phosphate margin indicated in the FAO standards is between 6 and $15 \mathrm{mg} / 1$ [19]. The average potassium concentration is relatively high and sometimes reaches $47 \mathrm{mg} / \mathrm{l}$.

On the contrary, the waters coming from the Oued Sebou are less rich in nutrients (NPK), with values lower than the EUT. They are of the order of $10 \mathrm{mg} / \mathrm{l}$ for total nitrogen and $3 \mathrm{mg} / \mathrm{l}$ for total phosphate, with the exception of nitrates, which have an average value of $4.2 \mathrm{mg} / \mathrm{l}$. This increase in nitrates is due to agricultural activities knowing that a large part of the land in the region is equipped with drainage systems linked to the R'DOM canal. A subsequent study confirms that in agricultural areas, watercourses related to drainage equipment are rich in nitrates [20].

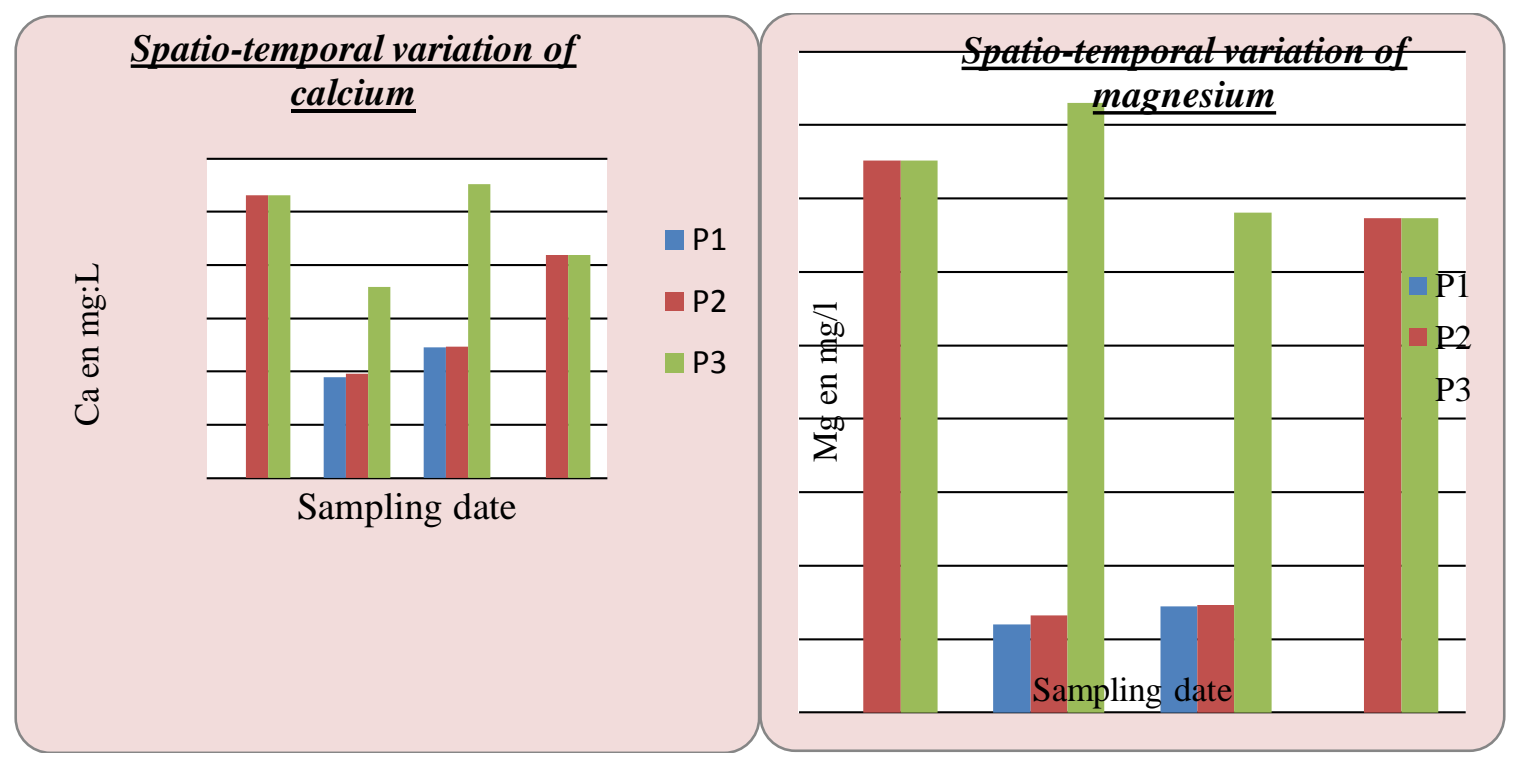




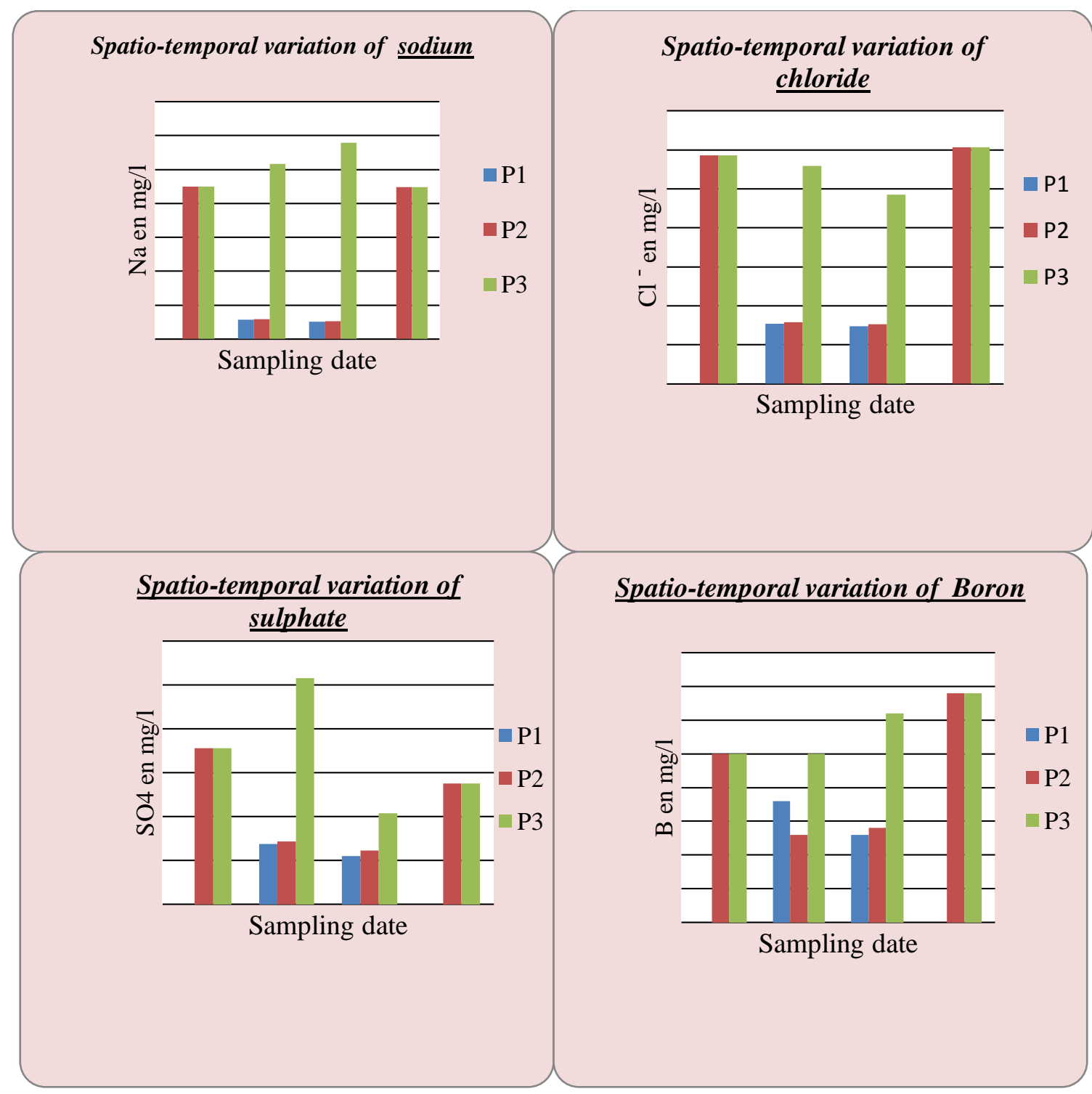

Fig.5:-Variation in the contents of minor nutrients

\section{Chlorides:-}

Specific ions such as chlorides, sodium and boron are toxic to some crops. This toxicity is often modified or reduced if the calcium is sufficiently available in the soil [21]. In our case, the values of the chloride are very high, they are between 448 and $580 \mathrm{mg} / \mathrm{l}$. However, our results are similar to those found during the sputtering of domestic wastewater in two different areas in Morocco [22-23].

\section{Boron:-}

At very low concentrations, boron is essential for plant growth; these needs are largely covered by wastewater [21]. For the waters of the WWTP, the concentrations do not exceed in most cases, the value set by the Moroccan standard of water intended for irrigation [16]. It reaches a value of $0.34 \mathrm{mg} / \mathrm{l}$ in a large number of samples.

\section{Sodium:-}

A large amount of sodium in the water affects the permeability of the soil and causes infiltration problems [21]. The phenomenon of sodium accumulation in soils is called sodization. The sodium absorption coefficient "SAR" corresponds to a value, without unit, defined empirically by the formula:

$\mathrm{SAR}:[\mathrm{Na}+] /[([\mathrm{Cac} 2+]+[\mathrm{Mg} 2+)] / 2] \mathbf{1 / 2}$ 
where the concentrations of ionic species, expressed in meq / L. In addition, the combination of the electrical conductivity of the WWTP water $(\mathrm{EC}>2.96 \mathrm{~ms} / \mathrm{cm})$ and the sodium adsorption coefficient $(8.56<$ SAR < 10.9), according to the classification model of Rievside irrigation water, these treated wastewater is classified in the watershed with high risk of salinization. On the contrary, the SAR of waters from Sebou wadi does not exceed 2, 07.

\section{Heavy metals:-}

Several heavy metals may be present in wastewater used for irrigation. In our case, we limit ourselves to the determination of eight elements present in the studied irrigation water, namely: $\mathrm{Cr}, \mathrm{Cd}, \mathrm{Pb}, \mathrm{Hg}, \mathrm{Cu}, \mathrm{Mn}, \mathrm{Fe}$ and $\mathrm{Zn}$. According to the obtained results, negligible values for $\mathrm{Cd}$ and $\mathrm{Hg}$ are observed, which are respectively of the order of $0.001 \mathrm{mg} / \mathrm{l}$ and $0.0001 \mathrm{mg} / \mathrm{L}$ on all sampling points, low values for $\mathrm{Ni}$ and $\mathrm{Cu}$. These results also reveal that the maximum $\mathrm{Pb}$ concentrations $(0.044 \mathrm{mg} / \mathrm{l})$ are recorded upstream of the discharge of the WWTP. The contents of $\mathrm{Cr}$, Iron, and $\mathrm{Cu}$ vary in a non-perceptible way from one point to the other. They are lower at the exit of the station. The levels obtained for all these elements are lower than the maximum values allowed for long-term use of irrigation water [19]. Zn concentrations are generally less than $2 \mathrm{mg} / \mathrm{l}$ for all the studied samples, they range between $0.1 \mathrm{mg} / \mathrm{l}$ and $0.23 \mathrm{mg} / \mathrm{l}$ are therefore conform to standards standards required for use in agriculture. The threshold set by FAO for irrigation water, above which toxicity problems could occur, is $0.2 \mathrm{mg} / \mathrm{l} \mathrm{in} \mathrm{Mn}$. In our case, the treated wastewater from the WWTP is characterized by relatively low levels of Mn at the points of operation and ranges from 0.01 to $0.12 \mathrm{mg} / \mathrm{l}$. The analysis of the results suggests that significant portion of these heavy metals in canal water can come from the inputs used (chemical fertilizers, insecticides) and industrial discharges from the city of Fes. These values remain inferior to those found during the characterization of Sebou waters at the exit of the city of Fes [24]. This may be justified by the change in the quality of the waters of Oued Sebou when it is regained by the waters of good quality from wadi Ouregha and these waters are not very favorable to irrigation.

\section{Conclusion:-}

In order to take into account the variation of the effluents, we have determined the physicochemical parameters of the treated wastewater from the DAR EL GUEDDARI WWTP used in agriculture and the waters that sometimes come from the Sebou wadi, to assess environmental impacts. The obtained results indicate that the physico-chemical quality of the WWTP water used for irrigation does not always meet the criteria. Indeed, they are characterized by low levels of oxygen, high levels of COD, BOD5, suspended solids, sulphates, chlorides and sodium. On the contrary, the pumped water from Oued Sebou represents an adequate dilution solution. The protection of these waters against the various contaminations is necessary and imperative so that they still serve in agriculture without risk of contamination. Dilution with good quality water and limitation to certain crops is also an alternative solution to support the use of these waters for irrigation. In the medium term, it is necessary to consider a lasting solution on the WWTP wastewater treatment process by aeration of the optional basins and the establishment of maturation ponds for tertiary treatment.

\section{References:-}

1. C.A.Scott ${ }^{1}$, N.I. Faruqui ${ }^{2}$, and Raschid-Sally ${ }^{3}$, (CAB Intenational (2004). Wastewater Use in Irrigated Agriculture: Management Challenges in Developing Countries

2. OMS (1989). L'utilisation des eaux usées en agriculture ET en aquaculture: recommandations a avisées sanitaires. Rapport d'un groupe scientifique de l'OMS. Organisation mondial de la santé, Rapport technique $\mathrm{n}^{\circ} 778$, Genève OMS. (1989). utilisation des eaux usées en agriculture et aquaculture

3. HAMDANI Imane : Réutilisation des Eaux Usées Epurées au MAROC : Expériences, Bilan et Perspectives Secrétariat d'état chargé de l'eau et de l'environnement / Département de l'Eau/ Maroc

4. Secrétariat d'Etat auprès du Ministère de l'Energie, des Mines, de l'Eau et de l'Environnement chargé de l'Eau et de l'Environnement (Décembre 2011).Projet de Renforcement des Capacités sur l'Utilisation sans danger des Eaux Usées en Agriculture Rapport National du Maroc - Programme mixte FAO/UNW-DPC/UNU-INWEH.

5. Haut-commissariat au plan. (2014). direction de la statistique, Maroc, Recensement général de la population : ville de DAR EL GUEDDARI.

6. A.B.H.S. (2013). Les ressources en eau dans le bassin du Sebou, Agence du Bassin Hydraulique de Sebou, Fès, Maroc

7. DR - 09-04 du CEAEQ (Québec/canada). (2004). «Mode de conservation pour l'échantillonnage des rejets liquides »

8. ONEP. (1993). «Prélèvement, conditionnement et stockage des échantillons d'eau : techniques utilisées à DLQ $(247 \mathrm{DC} / 12 / 93) »$ 
9. Norme Marocaine. (2001). « Détermination du pH, NM ISO $105235 »$.

10. Norme internationale ISO 5815-2, (1/4/2003).- détermination de la demande biochimique en oxygène après $n$ jours (DBOn).

11. Ministère du Développement durable, de l'Environnement et de la Lutte contre les changements climatiques. (2014). Détermination de l'azote total Kjeldahl et du phosphore total : digestion acide - méthode colorimétrique automatisée, MA. 300 - NTPT 2.0, Rév. 2, 16 p.

12. Centre d'expertise en analyse environnementale du Québec. (1999). Détermination de la demande chimique en oxygène dans les effluents : méthode de reflux en système fermé suivi d'un dosage par colorimétrie avec le bichromate de potassium -MA.315- DCO1.0 du 2/3/1999

13. Norme Marocaine. (1996). Détermination des matières en suspension, NM 03.7.052.

14. RODIER J. (2009). L'analyse de l'eau, 9eme éd. Dunod, Paris, 1, 1579

15. Ministère de L'Environnement du Maroc. (2002). Valeurs limites des rejets directs et indirects du Maroc. « Normes marocaines, Bulletin officiel du Maroc », $\mathrm{n}^{\circ} 5062$ du 30 ramadan 1423. Rabat

16. ministère de l'équipement et du ministère chargé de l'aménagement du territoire, de l'urbanisme, de l'habitat et de l'environnement, (2002). Arrêté conjoint $\mathrm{n}^{\circ}$ 1276-01 du 17 octobre 2002 portant fixation des normes de qualité des eaux destinées à l'irrigation.

17. OMS. (2012). directives pour l'utilisation sans risque des eaux usées des excréta et des eaux ménagères Volume II : l'utilisation des eaux usées en agriculture.

18. AYYACH .A, FATHALLAH .R, HBAIZ .E, FATHALLAH Z. CHOUKI.H, EL MIDAOUI A. (2016). Caractérisation physico-chimique et bactériologique des eaux usées de la station d'épuration de la ville de DAR EL GUEDDARI (MAROC) Département de chimie, Laboratoire de procédés de séparation, Faculté des sciences, Université Ibn Tofail, Kenitra, BP 1333, 14000, Maroc. Larhyss Journal, ISSN 1112-3680, n²8, Dec 2016, pp. 65-85

19. FAO. (Septembre 2003). L'irrigation avec des eaux usées traitées. Manuel d'utilisation. Organisation des Nations Unies pour l'Alimentation et l'Agriculture. Bureau Régional pour le Proche-Orient et Bureau sousrégional pour l'Afrique du Nord.

20. MALO.D, l'impact des activités agricoles sur la qualité de la rivière YAMASKA, université du Québec à Québec B.Sc. Spéc. Science Géologiquep :208

21. PETTYGROVE, G.S. and T. ASANO (Ed). (1984). Irrigation with reclaimed municipal wastewater. A Guidance Manual. California State Water Resources Control Board, Report No. 84, Sacramento.

22. ABOUELOUAFA M., EL HALOUANI H., KHARBOUA M., BERRICHI A. (2002). Caractérisation physicochimique et bactériologique des eaux usées brutes de la ville d'Oujda: canal principal et Oued Bounaïm. Actes de l'Institut agronomique et vétérinaire Hassan II. Vol.22, N³, pp.143-150

23. K. El Falaki et E.K. Lhadi. (2001). «Contribution à l'étude d'impact de l'épandage d'eaux usées brutes sur l'environnement dans la région de ZEMAMRA (PROVINCE D'EL JADIDA, MAROC) ». Laboratoire de l'eau et de l'environnement, Faculté des sciences, Université Chouaïb Doukkali., El Jadida (Maroc) DECHETS REVUE FRANCOPHONE D'ÉCOLOGIE INDUSTRIELLE - Nº $24-2001$

24. DERWICH E.1, BEZIANE Z.2, BENAABIDATE L.3, BELGHYTI D.4.( Juin 2008).Evaluation de la qualité des eaux de surface des Oueds Fes et Sebou utilisées en agriculture maraichères au Maroc. Centre Universitaire Régional d'Interface, Fès, Maroc. Larhyss/Journal n 07, pp. 59-77. 